\title{
Systemic Thought as a Necessity in Post Pandemic Age
}

\author{
Garcia J* \\ CES University, Colombia
}

*Corresponding author: John Garcia, CES University, Calle 67n57a25 Antioquia, Colombia, Tel: 033135786548; Email: johnc.garcia@udea.edu.co; Orcid ID is 0000-0002-3810-5583.

\section{Editorial}

Volume 4 Special Issue 1

Received Date: October 02, 2020

Published Date: October 07, 2020

DOI: $10.23880 /$ nhij-16000S1-006

\section{Abstract}

In this editorial, the author reflects on the importance of systemic thinking in the post-pandemic age, in the midst of the general and normalized crisis and between the technical dichotomy of care, its relationship with nursing care, based on some theoretical references as Jared Diamond, Martin Heiddeger and Michel Foucault

Keywords: COVID-19 pandemic; Systems theory; Nursing care; Compassion

One of the most important lessons learned from COVID-19 is that hyper-connections and interdependence are not only characteristics of human beings in the globalized world, but also, of life itself. When the real world is seen by the human eye, limits and differences appear everywhere, each thing has its own limit. Despite this, "nothing nor nobody can stay floating in a disconnected way. Among limits exist other things, perhaps subtle and imperceptible at first, the air between the bodies, forces among planets, the ground below us, several kinds of light waves" [1] . Hence, the caring of life ought to be understood in the same way. In other words, the care is interdependent and hyper connected of a countless of variables, which means, the nurse as care agent has the duty of thinking systematically.

A systemic thought involves accepting "We often think that our field of view and experience are complete, in that way, we do not notice gaps, voids or blind spaces. We do not realize that we do not see. Something similar happens with our knowledge; we do not know that we do not know." [2]. This problem is reproduced in several areas, sciences and disciplines, because of it, the connections of life seem to be invisible or even worst minimalized in the middle of the knowledge of each discipline. When I say each discipline, it means each field of science has different priorities and concepts of health, happiness and life. Although, it seems that no one is able to integrate these different perspectives. Thus, A dialogical and hermeneutic approach is a necessity for understanding that the part is in the whole, the whole is also in the part which in turn is also immersed itself in the whole.

We are in a crisis, a crisis inside another crisis, or even inside several crises, due to some crises having particular characteristics that can produce several interrelated consequences, and these ones by themselves turn into another crisis. The consequences' net of just one crisis is that huge and hyper connected, that just removing the initial cause, the final consequences do not disappear, on the contrary, they continue growing. The most troubling answer among us is to normalize crises, to avoid the problem and thereby think of possible solutions. Are we going to keep thinking everything was okay? As Jared Diamond wrote [3], "the first step in dealing with the crisis is to recognize it". Just in that way, recognizing our limitations and responsibilities, we could improve ourselves and our caring practices.

Recognizing that we are limited, is to accept the otherness as a necessity, the otherness conforms the human being, the nurse as human being is confirmed by other, a dilogical conformation of opposites is established in this home called earth planet, and by this time, called present life, it is mandatory the presence and relationship among all of them. That relationship is a circular relationship. For instance, a nurse is really a nurse in a care relationship, the subject of care needs someone to take care of him, the care as an act 
needs both, and of course a context. Another example, health dehumanization could be a consequence of technicism and several science achievements, butalso health dehumanization is caused by what Niestzche named "death of God" [4]. Also, it is caused by extreme individualism in the middle of the capitalism age, all this, is just one crisis perspective. There are "medicalization and pharmaceuticalization" (with pills and techniques) of everyday life, so the care of life as a value has been depreciated [5]. Besides there are economic, political and cultural factors also involved in this vicious circle. On the one hand, it is impossible to give up on technological advances, in fact, these are necessary in an ever-changing world. On the other hand, we are an ontological mixture between technique and caring, which is well illustrated through the myth of care [6], in this sense; it seems that one of the human existentials, the technique, was prevailing over the other, the care.

Caring in the COVID-19 age has been an important challenge at different levels of care. At the individual level, patients and professionals have concerns and fears exacerbated by the possibility of getting sick or making someone ill, and also by fake news or misinformation surround the topic. Expressions like "In the Hospital they (Nurses and physicians) are killing us (Patients)" repeated without context through TV programs or social media have caused a lot of harm, sowing mistrust in health personnel [79]. There are some physical barriers, masks, isolation rooms, social distance, so the unique way for communication of bodies is through the eyes. Therefore, care as a relationship is much colder, distant and just a little bit effective.

At the medium level, Hospitals do not have enough resources, which increases concerns about the health quality, there is a disproportion between supply and demand that translates into making decisions about who lives and who does not. There is also greater work overload, lower quality of care and a loss of credibility in health institutions. At the global level Governments have to decide between the economy and health, which at first supposes a breakdown of customs, such a change, amid the underlying inequity can be tragic for the vast majority and acceptable for the rest. All these changes seek to hide behind the curtain of A new normality, which is something similar to "Speech of the gallows" [10] in which the condemned to death testified his guilt and the justice of his sentence. Now, unemployment, labor informality, the precariousness of health systems, great social inequity, fear of the other and stigmatization are part of a "normality new", in which everything seems to be justified

So, How to revitalize care in the face of mastery of technique and in the middle of COVID-19 age? A complex problem requires complex answers, to understand the problem and get closer to answers complex thinking is necessary. Once the crisis is recognized. Responsibility must be accepted, responsibility from an ecological perspective [11], in which, as a result of the exploitation of nature without any precautionary principle, habitats have been modified , species exterminated, temperature increased, droughts caused, and that is just to mention some changes, changes that by the way are largely irreversible and because they are part of a latent and slow crisis (although it is getting faster and faster) not enough attention has been paid and it is still called climate change and not "ecological crisis", from which a new crisis has emerged. And of course the responsibility at the individual level, here individually, those who do not have the means to follow the recommendations and avoid the spread of the virus are not included. The word means could be very big in this sense, food, water, soap, housing, information, education, health services, among others. But if we include those who, even having the means, did not follow the indications and of course, all those who have corrupted and continue to corrupt politics, health, education, housing and the welfare of the population in general, they do have a great responsibility in the present crisis, the underlying ones and the ones to come. They are also responsible, those who, having the possibility did not extend their hand to the person who asked for it, did not expand their circles of empathy, but on the contrary, reduced them. Also those who used the situation to take advantage of the needs of others and those who were part of the chains of disinformation, false news and the distribution of fear. But they are also responsible for so many innocent, vile pawns of a system in which evil is made so banal that it becomes a mere duty [12], through a discontinuity between the motivation of an action and its consequences.

Accepting responsibility allows responding. How should we respond? First of all, we should respond in a systematic way, thinking about all possible relations, in a circle way. An answer implies the otherness, so $i$ which is an answer that starts from otherness? I dare to say "care". A systematic care, in short terms, a care that takes into account the ecological, social, political, economic, cultural and health factors, the relationships between them and with us. A care that moves between idealism and realism, that builds reality and knowledge with others and for others. It requires the empowerment and participation of care agents in diverse areas. Today more than ever a diversification of care is required, to take care of care. A care that gives real importance to the possibility of sharing descriptions and explanations with others that allows a closer approach to a more complex view of the universe. Responding is also an act of detaching the self to welcome the other, it is an ecstatic movement that transcends the sense and noceable barriers, it is thinking about the finitude of life, a past history, a present life and a future to come. 


\section{References}

1. Bateson G (2002) Mind and Nature: a necessity unity. Hampton Pres, Cresskill, N Y.

2. Garciandía I (2011) JA Thinking Systems: An Introduction to Systems Thinking, $2^{\text {nd }}(\mathrm{edn})$, Editorial Pontificia Universidad Javeriana, Bogotá, D.C.

3. Diamond J (2019) Upheaval: turning points for nations in crisis, $1^{\text {st }}(\mathrm{edn})$, Little, Brown and Company, New York.

4. Nietzsche FW, Kaufmann WA (1974) The gay science: with a prelude in rhymes and an appendix of songs, $1^{\text {st }}(\mathrm{edn})$, Vintage Books, New York

5. Meneu R (2018) Life medicalization and the recent appearance of pharmaceuticalization. Farmacia hospitalaria 42(4): 174-179.

6. Heidegger M (1988) Being and time. Harper and Row,
New York.

7. Salamanca LR (2020) Publication on 'COVID-19 Cartel' includes false information and misinterprets protocols for handling deceased.

8. They accuse doctors of killing patients in the Ecatepec hospital. In: Excelsior.

9. (2020) Doctors in Antioquia rejected accusations of alleged COVID cartel. In: Blu Radio.

10. Foucault M, Sheridan A, Penguin (1977) Discipline and punish: the birth of the prison. Penguin Books, London.

11. Bonilla-Aldana DK, Dhama K, Rodriguez-Morales AJ (2020) Revisiting the One Health Approach in the Context of COVID-19: A Look into the Ecology of this Emerging Disease. Adv Anim Vet Sci 8(3): 234-237.

12. Arendt H (2006) Eichmann in Jerusalem: a report on the banality of evil. Penguin Books, New York, NY. 